\title{
Discovery of termitophilous rove beetles associated with Formosan subterranean termite Coptotermes formosanus in Taiwan, with the first larval description for the tribe Termitohospitini (Coleoptera: Staphylinidae)
}

\author{
Wei-Ren LIANG ${ }^{1,2)}$, Munetoshi MARUYAMA ${ }^{2)}$, Taisuke KANAO ${ }^{3)}$, Ryûtarô IWATA ${ }^{4}$ \& Hou-Feng LI',*) \\ 1) Department of Entomology, National Chung Hsing University, 145 Xingda Rd., Taichung, 40227, Taiwan; \\ e-mails: leif2051@gmail.com; houfeng@nchu.edu.tw \\ 2) The Kyushu University Museum, Fukuoka 812-8581, Japan; e-mail: dendrolasius@gmail.com \\ 3) Okinawa Institute of Science and Technology Graduate University, Okinawa 904-0495, Japan; e-mail: kanatai1225@gmail.com \\ ${ }^{4)}$ Department of Forest Science and Resources, College of Bioresource Sciences, Nihon University, Fujisawa 252-0880, Japan; \\ e-mail: iwata.ryutaro@nihon-u.ac.jp \\ ") corresponding author: houfeng@nchu.edu.tw
}

Accepted:
$29^{\text {th }}$ January2020
Published online:
$29^{\text {th }}$ February 2020

\begin{abstract}
The Formosan subterranean termite, Coptotermes formosanus Shiraki, 1909 (Blattodea: Rhinotermitidae), is a well-known pest of wood structures. Its native range has been widely investigated for potential implications for pest control strategies. Termitophilous staphylinid species of the genera Japanophilus Maruyama \& Iwata, 2002 and Sinophilus Kistner, 1985 found in nests of $C$. formosanus have been used to infer the native range of their host termite. Herein, we extend the range of these two genera to include Taiwan, the type locality of $C$. formosanus. Taiwanese specimens were identified as $J$. hojoi Maruyama \& Iwata, 2002 and S. yukoae Maruyama \& Iwata, 2002 based on morphological and molecular data. The first-instar larva of $J$. hojoi is described, the first known immature stage of the tribe Termitohospitini (Coleoptera: Staphylinidae: Aleocharinae).
\end{abstract}

Key words. Coleoptera, Staphylinidae, Aleocharinae, Rhinotermitidae, social insect symbionts, termitophiles, Taiwan

Zoobank: http://zoobank.org/urn:lsid:zoobank.org:pub:7544D0EE-F85A-4603-BADE-1C34764A7985

(C) 2020 The Authors. This work is licensed under the Creative Commons Attribution-NonCommercial-NoDerivs 3.0 Licence.

\section{Introduction}

The Formosan subterranean termite, Coptotermes formosanus Shiraki, 1909 (Rhinotermitidae), is an economically important pest of wood structures (PIMENTEL et al. 2005) and was described from Taiwan (SHIRAKI 1909). It has been proposed that $C$. formosanus might be endemic to several East Asian countries (Li et al. 2009, MARUYAMA et al. 2012) and spread to urban regions of the world via human activities (EvANs et al. 2013). Determining the native distribution of an invasive pest is crucial for improving pest control from biological and ecological perspectives. Previous studies have attempted to determine the native range and introduction routes of $C$. formosanus using population genetics. However, multiple introduction routes are likely and global genetic variation among the populations is low (WANG \& Grace 2000, Austin et al. 2006, Li et al. 2009, Husseneder et al. 2012). The extent of the native range of $C$. formosanus is still uncertain among East Asian countries, such as Japan, China, and Taiwan.

Termitophiles, organisms closely associated with termite societies, have diverse host interactions, such as obligatory predators, parasites, food thieves, and symphiles (KISTNER 1969, KISTNER 1979). Symphiles are often species-specific to a host and integrate into the termite society through mechanisms such as chemical mimicry or Wasmannian mimicry (KISTNER 1979). Since some termitophiles are species-specific and unlikely to be transported by human activities or able to cross natural barriers by themselves, their presence within termite nests is ideal for indicating the native range of their host termite (KISTNER 1985, MARUYAMA et al. 2012). 


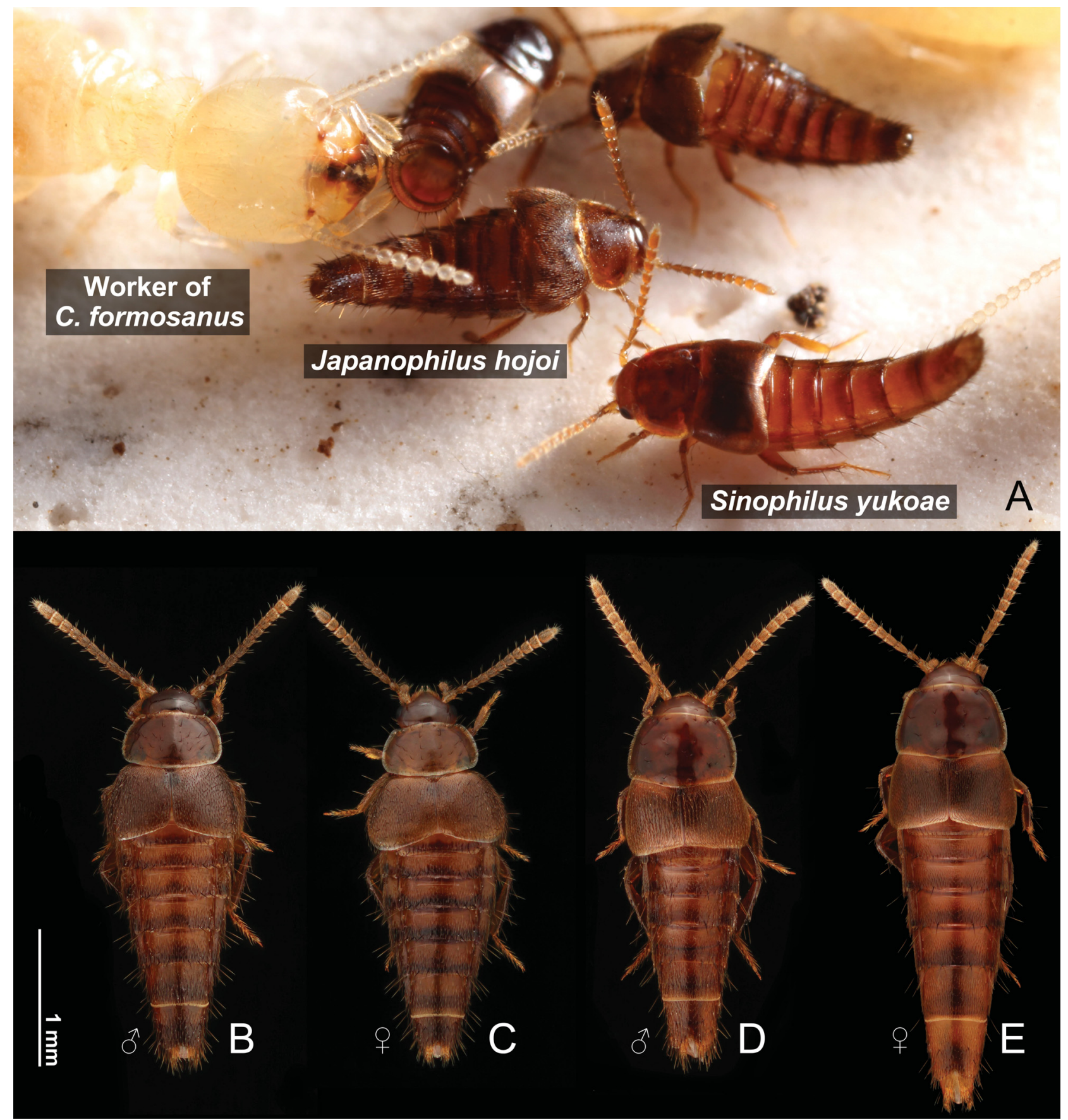

Fig. 1. Habitus of Termitohospitini species associated with the Formosan subterranean termite in Taiwan. A - living habitus of Japanophilus hojoi Maruyama \& Iwata, 2002 and Sinophilus yukoae Maruyama \& Iwata, 2002, showing a worker of Coptotermes formosanus Shiraki, 1909 grooming the abdomen of a S. yukoae; B-E - dorsal habitus of males and females of J. hojoi (B and C) and S. yukoae (D and E).

Three species of rove beetles belonging to two genera, Japanophilus Maruyama \& Iwata, 2002 and Sinophilus Kistner, 1985 have been found in nests of C. formosanus and were used in inferring the native range of the termite to China and Japan (KistNer 1985, MaruYAMA \& IwATA 2002, Maruyama et al. 2012).

Recently, these two genera, Japanophilus and Sinophilus, were also discovered in Taiwan (Fig.1). However, their species identities had not been confirmed previously. The present study uses morphological and molecular methods to identify these species. Furthermore, several putative larvae of these two termitohospitine genera were found and their identities were investigated.

\section{Material and methods}

Collecting methods for Termitohospitini spp. The Termitohospitini spp. examined in the present study were collected by dissecting deadwood materials infested by $C$. formosanus or by setting out wooden baits, originally used as a termite population monitoring technique in pest control. The wooden bait is a bundle of radiata pine slabs (Pinus radiata D. Don; 18 pieces, 8.5 by 13 by $0.2 \mathrm{~cm}$ ) used in the modified underground monitoring station of CHIU et al. (2016), which was originally designed by $\mathrm{Su}$ et al. (1993). The wooden baits were set up under two rotten fallen logs infested by $C$. formosanus at Mt. Dakershan, Miaoli County, Taiwan; the 
Table 1. Material examined for this study. Abbreviations of specimens examined: J - Japanophilus hojoi, adult; JL - Japanophilus hojoi, larva; S - Sinophilus yukoae, adult.

\begin{tabular}{|c|c|c|c|c|}
\hline Voucher code & Locality & Label data & Specimens & GenBank accession \# \\
\hline \multicolumn{5}{|l|}{ JAPAN } \\
\hline KST47 & $\begin{array}{l}\text { Kagoshima } \\
\text { Pref. }\end{array}$ & Yaku-shima Is.: Onoaida-Rindô, 9.ix.2012, T. Kanao leg. & $1 \mathrm{~J}$ & MN747900, MN747909 \\
\hline KST287 & $\begin{array}{l}\text { Kagoshima } \\
\text { Pref. }\end{array}$ & $\begin{array}{l}\text { Yushima-chô: Satsuma-Sendai-shi, 20.xii.2015, H. Hirose } \\
\text { leg., 8.x.2017, taken out by T. Sasaki \& H. Hirose. }\end{array}$ & $1 \mathrm{~S}$ & MN747904 \\
\hline KST92 & Okinawa Pref. & $\begin{array}{l}\text { Okinawa-jima Is.: Kunigami-gun: Oku, 6.vii.2012, T. } \\
\text { Kanao leg. }\end{array}$ & $1 \mathrm{~S}$ & MN747902, MN747906 \\
\hline KST133 & $\begin{array}{l}\text { Wakayama } \\
\text { Pref. }\end{array}$ & Enjugahama, 3.vii.2015, T. Kanao leg. & $1 \mathrm{~S}$ & MN747903, MN747905 \\
\hline \multicolumn{5}{|l|}{ TAIWAN } \\
\hline TW4298 & Miaoli Co. & $\begin{array}{l}\text { Zhuolan Township: Dakershan: } 24.329187^{\circ} \mathrm{N} \text {, } \\
120.895656^{\circ} \mathrm{E}, 645 \mathrm{~m}, 27 . x i i .2014 \text {, under the bark of } \\
\text { rotten wood with Coptotermes formosanus, C.-Y. Quo, } \\
\text { K.-C. Kuan, and W.-R. Liang leg. }\end{array}$ & $7 \mathrm{~J}$ & \\
\hline TW4302 & Miaoli Co. & same as TW4298, but 18.iii.2015, W.-R. Liang leg. & 4J, 6JL (1JL for SEM) & \\
\hline TW4305 & Miaoli Co. & same as TW4298, but 12.iv.2015, W.-R. Liang leg. & $\begin{array}{l}8 \mathrm{~J}, 8 \mathrm{~S}, 5 \mathrm{JL} \\
(1 \mathrm{~J} \text { for sequencing) }\end{array}$ & MN747899, MN747911 \\
\hline TW4324 & Miaoli Co. & same as TW4298, but 13.v.2015, W.-R. Liang leg. & $1 \mathrm{~J}, 1 \mathrm{JL}$ & \\
\hline TW4329 & Miaoli Co. & same as TW4298, but 19.vi.2015, W.-R. Liang leg. & $1 \mathrm{~J}, 1 \mathrm{~S}, 1 \mathrm{JL}$ & \\
\hline TW7912-7917 & Miaoli Co. & same as TW4298, but 19.vii.2015, W.-R. Liang leg. & $2 \mathrm{~J}, 4 \mathrm{~S}, 1 \mathrm{JL}$ & \\
\hline TW7910, 7911 & Miaoli Co. & same as TW4298, but 29.viii.2015, W.-R. Liang leg. & $\mathrm{J} 2,4 \mathrm{~S}$ & \\
\hline TW7328 & Miaoli Co. & same as TW4298, but 4.iv.2018, W.-R. Liang leg. & 2S (1S for sequencing) & MN747901, MN747908 \\
\hline TW7329-1-5 & Miaoli Co. & same as TW4298, but 30.iv.2018, W.-R. Liang leg. & 7JL (5JL for sequencing) & MN747912-MN747916 \\
\hline TW7899-7901 & Nantou Co. & $\begin{array}{l}\text { Shuili Township: } 23.8129^{\circ} \mathrm{N} ; 120.853537^{\circ} \mathrm{E}, 283 \mathrm{~m} \text {, } \\
\text { in termite control bait with Coptotermes formosanus, } \\
\text { 5.vii.2018, H.-T. Yeh leg. }\end{array}$ & $\begin{array}{l}3 \mathrm{~J}, 1 \mathrm{~S} \\
(1 \mathrm{~J}, 1 \mathrm{~S} \text { for sequencing) }\end{array}$ & MN747907, MN747910 \\
\hline TW7143 & $\begin{array}{l}\text { New Taipei } \\
\text { City }\end{array}$ & $\begin{array}{l}\text { Tucheng District: } 24.98519^{\circ} \mathrm{N} 121.4681^{\circ} \mathrm{E}, 22 \mathrm{~m} \text {, } \\
\text { 15.viii.2017, with C.f., F.-S. Hu leg. }\end{array}$ & $1 \mathrm{~S}$ & \\
\hline TW7150 & $\begin{array}{l}\text { New Taipei } \\
\text { City }\end{array}$ & $\begin{array}{l}\text { Taishan District: } 25.03645^{\circ} \mathrm{N} 121.4228^{\circ} \mathrm{E}, 15 \mathrm{~m} \text {, } \\
\text { 20.viii.2017, with Coptotermes formosanus, F.-S. Hu leg. }\end{array}$ & $1 \mathrm{~S}$ & \\
\hline TW4109 & Taipei City & $\begin{array}{l}\text { National Taiwan University: } 25.01926^{\circ} \mathrm{N} 121.5436^{\circ} \mathrm{E}, 16 \\
\mathrm{~m}, 19 . \mathrm{ii} .2013 \text {, in wooden stakes infested by Coptotermes } \\
\text { formosanus, H.-F. Li leg. }\end{array}$ & $2 \mathrm{~S}$ & \\
\hline TW4112 & Taipei City & same as TW4109, but 18.iii.2013 & $2 \mathrm{~S}$ & \\
\hline TW4114 & Taipei City & same as TW4109, but 1.iv.2013 & $1 \mathrm{~S}$ & \\
\hline TW4118 & Taipei City & same as TW4109, but 21.v.2013 & $1 \mathrm{~S}$ & \\
\hline TW4154 & Taipei City & $\begin{array}{l}\text { same as TW } 4109 \text {, but } 25.01872^{\circ} \mathrm{N} 121.54334^{\circ} \mathrm{E}, 16 \mathrm{~m} \text {, } \\
\text { 23.vii.2013 }\end{array}$ & $1 \mathrm{~S}$ & \\
\hline TW7141 & Taipei City & $\begin{array}{l}\text { Beitou District: } 25.1549^{\circ} \mathrm{N} 121.504^{\circ} \mathrm{E}, 306 \mathrm{~m}, \\
\text { 16.viii.2017, with Coptotermes formosanus, F.-S. Hu leg. }\end{array}$ & $1 \mathrm{~S}$ & \\
\hline TW4257 & Taichung City & $\begin{array}{l}\text { National Chung Hsing University: } 24.122879^{\circ} \mathrm{N}, \\
120.674147^{\circ} \mathrm{E}, 64 \mathrm{~m} \text {, in dead tree branches with Cop- } \\
\text { totermes formosanus, 31.v.2014, W.-R. Liang leg. }\end{array}$ & $1 \mathrm{~S}$ & \\
\hline TW7152 & Yilan Co. & $\begin{array}{l}\text { Yuanshan Township: } 24.71473^{\circ} \mathrm{N} 121.7391^{\circ} \mathrm{E}, 11 \mathrm{~m} \text {, } \\
\text { 3.viii.2017, with Coptotermes formosanus, F.-S. Hu leg. }\end{array}$ & $1 \mathrm{~S}$ & \\
\hline TW7146 & Yilan Co. & $\begin{array}{l}\text { Yilan City: } 24.74603^{\circ} \mathrm{N} 121.7548^{\circ} \mathrm{E}, 10 \mathrm{~m}, 9 . \mathrm{viii} .2017 \text {, } \\
\text { with Coptotermes formosanus, F.-S. Hu leg. }\end{array}$ & $1 \mathrm{~J}, 1 \mathrm{~S}$ & \\
\hline
\end{tabular}

first author (WRL) had collected several Termitohospitini spp. in these logs on 27 December 2014. The wooden baits were renewed and the old baits were collected every 1 or 2 months in 2015 and 2018. The old wooden baits infested by C. formosanus were dissected in the laboratory to look for termitophilous beetles. In the period of wooden bait installation, potential larvae of Termitohospitini were collected in the litter and soil near the wooden bait occupied by $C$. formosanus, together with adults of two termitohospitine genera: Japanophilus and Sinophilus.

Identification of adult and immature stage. Some of the adult beetles collected from the field were dissected and compared with the original descriptions of Japanophilus hojoi and Sinophilus spp. The Taiwanese adult/ larval beetles were molecularly identified by comparing them with Japanese specimens. The beetles used for molecular sequencing were preserved in 95\% ethanol. Genomic DNA was extracted by immersing the whole body of the larval or adult beetle in the DNA Extraction Kit (BuccalAmp, Epicentre, Madison, WI) or DNeasy Blood and Tissue Kit (Qiagen, Tokyo, Japan). Partial 16S ribosomal RNA gene (16S) and cytochrome oxidase 1 gene (CO1) sequences were amplified through polymerase chain reaction (PCR) with primers 16 saR (5'-CGCCTGTTTATCAAAAACAT) and 16sb (5'-CTCCG- 
GTTTGAACTCAGATCA) for 16S, and TL2-N-3014PAT (5'-TCCAATGCACTAATCTGCCATATTA) and C1-J-2183JERRY (5'-CAACATTTATTTTGATTTTTTGG) for CO1. The total $25.3 \mu \mathrm{l}$ PCR mixture contained 19.8 $\mu \mathrm{l}$ of ddH2O, $0.5 \mu \mathrm{l}$ of dNTP mixture $(25 \mathrm{mM}), 0.5 \mu \mathrm{l}$ of Taq DNA polymerase, forward and reverse primers $(0.5$ $\mu \mathrm{l}$ each, $10 \mathrm{mM}), 2.5 \mu \mathrm{l}$ of $10 \mathrm{X}$ reaction buffer, and $1 \mu \mathrm{l}$ of the beetle DNA template. PCR thermal cycle reaction included a predenaturation process at $94{ }^{\circ} \mathrm{C}$ for $2 \mathrm{~min}$, followed by 35 cycles of denaturation at $94{ }^{\circ} \mathrm{C}$ for $40 \mathrm{~s}$, annealing at $55^{\circ} \mathrm{C}$ for $1 \mathrm{~min}$, extension at $72{ }^{\circ} \mathrm{C}$ for 40 $\mathrm{s}$, and a post extension at $72{ }^{\circ} \mathrm{C}$ for $10 \mathrm{~min}$. The DNA sequences are available in GenBank (accession numbers: MN747899-MN747916). The sequence data were edited and aligned in BioEdit 7.0.5 (HALL 1999) using the ClustalW algorithm. Aligned data were analyzed using maximum likelihood in the MEGA X (KumAR et al. 2018) using the GTR $+\mathrm{G}$ (for 16S) and GTR $+\mathrm{I}$ (for CO1) models selected as best fitting the data in jModeltest (POSADA 2008); bootstrap values were calculated using 500 replicates; sequences of Myllaena audax Casey, 1911 (Aleocharinae: Myllaenini) from Elven et al. (2012) were used for outgroup data.

Larval description and general habitus examination. The larval beetles were preserved in $70-95 \%$ ethanol. To prepare microscope slides, the larvae were cleared in $10 \% \mathrm{KOH}$, rinsed with water, and finally put in a $(1: 1)$ mixture of hand sanitizer (PURELL, GOJO Industries, Inc. Akron, $\mathrm{OH}$ ) and propylene glycol on a concavity slide for temporary observation. The specimens were examined under a Leica ${ }^{\circledR}$ M205 C stereomicroscope and a Leica ${ }^{\circledR}$ DM750 microscope with a drawing tube and measured using an ocular micrometer. The larval description style and terminology follow Ashe \& Watrous (1984) and STANIEC et al. (2009). Line drawings of larvae were made using Adobe Illustrator CC. 2019 (Adobe Inc., Mountain View, CA). The specimen for scanning electron micrograph (SEM) was dehydrated with HMDS (hexamethyldisilazane). The dehydrated specimen was sputter-coated with gold, and images were obtained using a scanning electron microscope (JCM-6000 NeoScope ${ }^{\mathrm{TM}}$ Versatile Benchtop SEM, JEOL, Tokyo, Japan) at $5 \mathrm{kV}$. The habitus photographs of beetles were taken from multiple focal planes by Leica MC170 HD digital camera or Canon EOS $760 \mathrm{D}$ with a macro lens (Canon Inc., Tokyo, Japan), and then combined using an automontage software CombineZP (HADley 2010). Photographic plates were created and edited using Adobe Photoshop CS6 (Adobe Inc., Mountain View, CA).

Specimen depositories. Examined materials are listed in Table 1 . The depository of the specimens is indicated by the following prefixes:

KST Taisuke Kanao personal collections [the specimens are coded with KST\# (\#: serial number)];

TW NCHU Termite collection, Department of Entomology, National Chung Hsing University, Taichung, Taiwan [the termitophiles are preserved with host termites and each termite colony sample is coded with TW\# (\#: serial number)].

\section{Results}

\section{Identity of adults and larvae of Termitohospitini} in Taiwan

Adults of the Taiwanese specimens were identified as the Japanese species Japanophilus hojoi and Sinophilus yukoae using morphology and sequence data with $<0.6 \%$ difference in $16 \mathrm{~S}$ (563-bp) and $<0.4 \%$ difference in $\mathrm{CO} 1$ (844-bp) sequences compared with specimens from Japan (Fig. 2). The examined larvae were collected together with adults of J. hojoi and S. yukoae in the same rotten wood. We compared the 16S rRNA gene sequences of 5 larvae (TW7329-1-5) with adults of those two species. Larval $J$. hojoi $16 \mathrm{~S}$ sequences were identical to adults from Taiwan and together clustered with a specimen from Japan (Fig. 2).

\section{List and distribution of Japanophilus and Sinophilus}

\section{Genus Japanophilus Maruyama \& Iwata, 2002}

\section{Japanophilus hojoi Maruyama \& Iwata, 2002}

Type locality. Japan: Kyushu: Kagoshima Pref.: Tokara-Suwanose-jima Is.

Distribution. Japan (Honshu, Kyushu, and Ryukyu Islands): Kagoshima Pref.: Amami-Ôshima Is., Naka-no-shima Is., Satsuma-Sendai-shi, Tokara-Suwanose-jima Is., and Yaku-shima Is. (MaruYama \& IwATA 2002, KANAO et al. 2019); Wakayama Pref.: Kushimoto and Nachi-Katsuura (MAruyama et al. 2012), and Taiwan (Miaoli, Yilan, and Nantou) by the present study (Fig. 3).

\section{Genus Sinophilus Kistner, 1985}

\section{Sinophilus xiai Kistner, 1985}

Type locality. China: Zhejiang: Jinhu.

Distribution. China: Guangdong and Zhejiang (KISTNER 1985).

Note. Schülke \& SMetana (2015) list the species also from Guizhou, but complete data about this record were not published; they may be based on a typo.

\section{Sinophilus rougemonti Pace, 1998}

Type locality. Hong Kong: Kadoorie Agricultural Research Centre.

Distribution. Hong Kong: Tai Po (PACE 1998).

\section{Sinophilus yukoae Maruyama \& Iwata, 2002}

Type locality. Japan: Okinawa Pref.: Iriomote-jima Is.

Distribution. Japan (Honshu, Kyushu, and Ryukyu Islands): Kagoshima Pref.: Satsuma-Sendai-shi and Yaku-shima Is. (KANAO et al. 2019); Okinawa Pref.: Iheya-jima Is., Iriomote-jima Is., Ishigaki-jima Is., and Okinawa-jima Is. (Maruyama \& IWATA 2002, KANAO et al. 2019); Wakayama Pref.: Nachi-Katsuura and Kushimoto (Maruyama et al. 2012), and Taiwan (Miaoli, Nantou, New Taipei City, Taipei City, Taichung City and Yilan) by the present study (Fig. 3). 

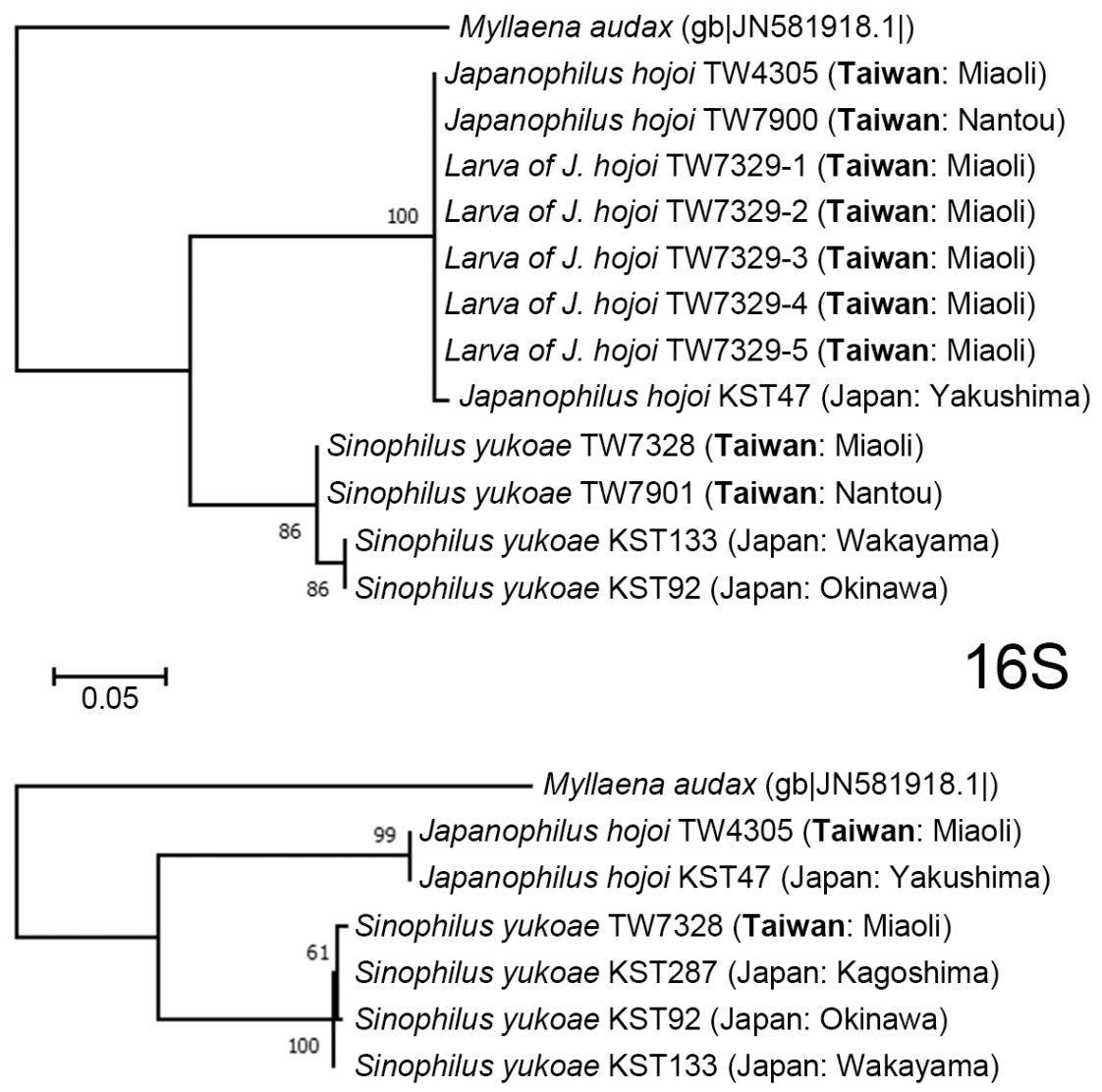

0.05

$\mathrm{CO} 1$

Fig. 2. Maximum likelihood tree of $16 \mathrm{~S}$ and CO1 sequences of Japanese and Taiwanese Termitohospitini species. Myllaena audax Casey, 1911 (Aleocharinae: Myllaenini) was used as outgroup.

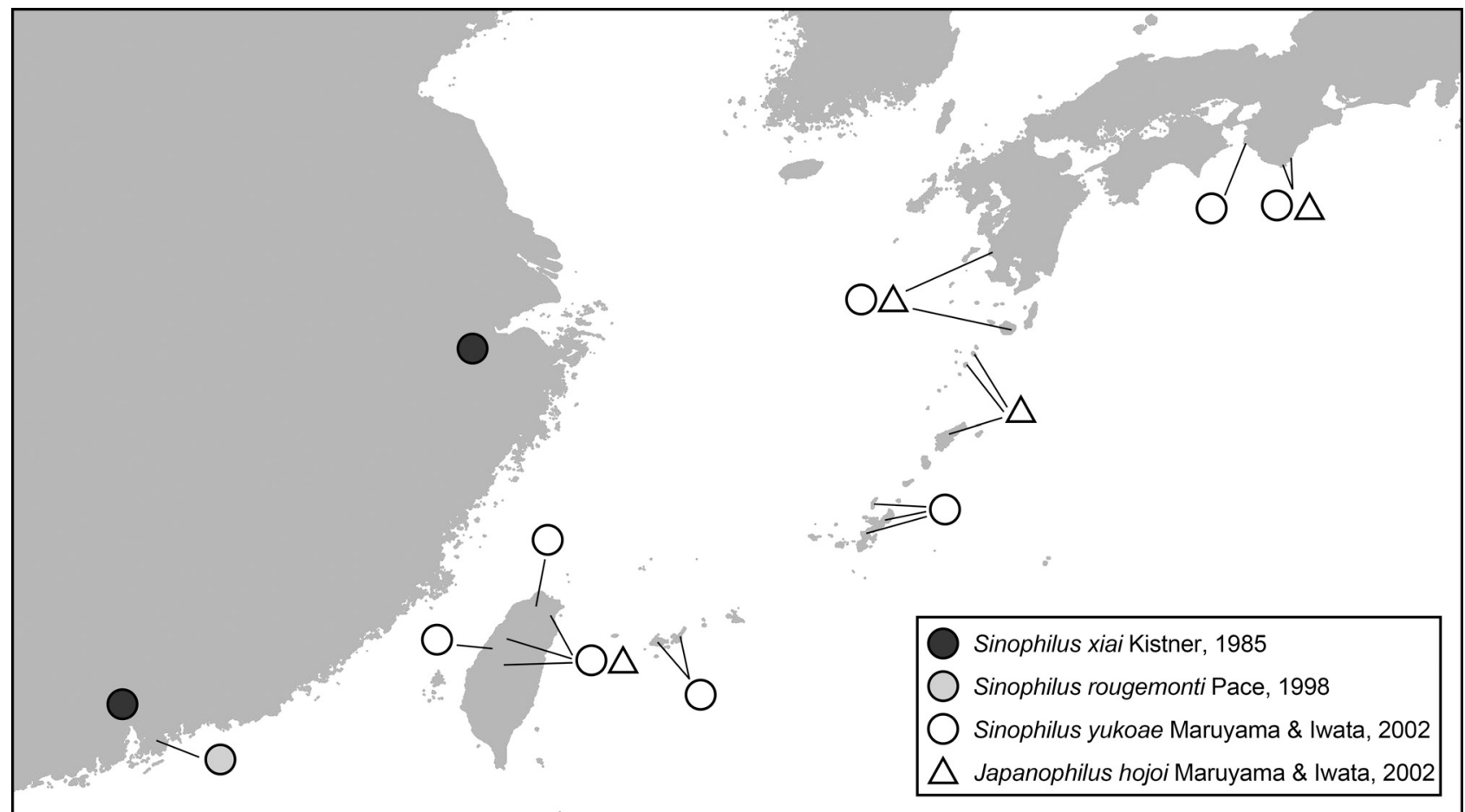

Fig. 3. Distribution map of Japanophilus hojoi Maruyama \& Iwata, 2002 and Sinophilus spp. The distribution data of China and Japan are from KISTNER (1985), Pace (1998), Maruyama et al. (2012), and Kanao et al. (2019). 


\section{Description of the first larval instar of Japanophilus hojoi}

Measurements $(\mathrm{n}=5)$ : length, $1.25-1.30 \mathrm{~mm}$; head width approximately $0.28-0.29 \mathrm{~mm}$; antennal length approximately $0.14 \mathrm{~mm}$; maximum body width approximately $0.32 \mathrm{~mm}$ (at anterior corners of pronotum). General body form (Fig. 4) elongate, nearly parallel-sided in dorsal view, slightly flattened dorsoventrally. Body color (Fig. 4) pale, head capsule, mandible, sensory appendage of antennomere II, and basal joints of tibia very light orange-brown; antennomere III black (Fig. 4).

Head (Figs 4, 5). Weakly sclerotized; length subequal to width; dorsal ecdysial lines (Es) bifurcate posterior to mid- dle of head; stemmata absent. Head setae and campaniform sensilla as shown in Fig. 5. Chaetotaxy of dorsal part of head (Fig. 5A) with 6 pairs of epicranial macrosetae (codes: Ed1, Ed3, El1, El3, Em1-2), 4 pairs of posterior microsetae (P1-4), 3 pairs of epicranial campaniform sensilla (Ec1-3), 8 pairs of frontal setae (codes: Fd1-3, Fl1-4, Fm1). Lateral parts of head (Fig. 5B) with: 4 temporal setae (T1, T2), 4 lateral setae (L1-2). Ventral side (Fig. 5C) with 2 ventral setae (V1), 6 ventral lateral setae (V11-3) and 2 ventral campaniform sensilla (Vc1). Mandibles (Fig. 6A), nearly symmetrical in size and shape; form elongate, slender with broader lobe at molar region; with distinct preapical tooth; an obtuse angle appearing like a tooth at middle

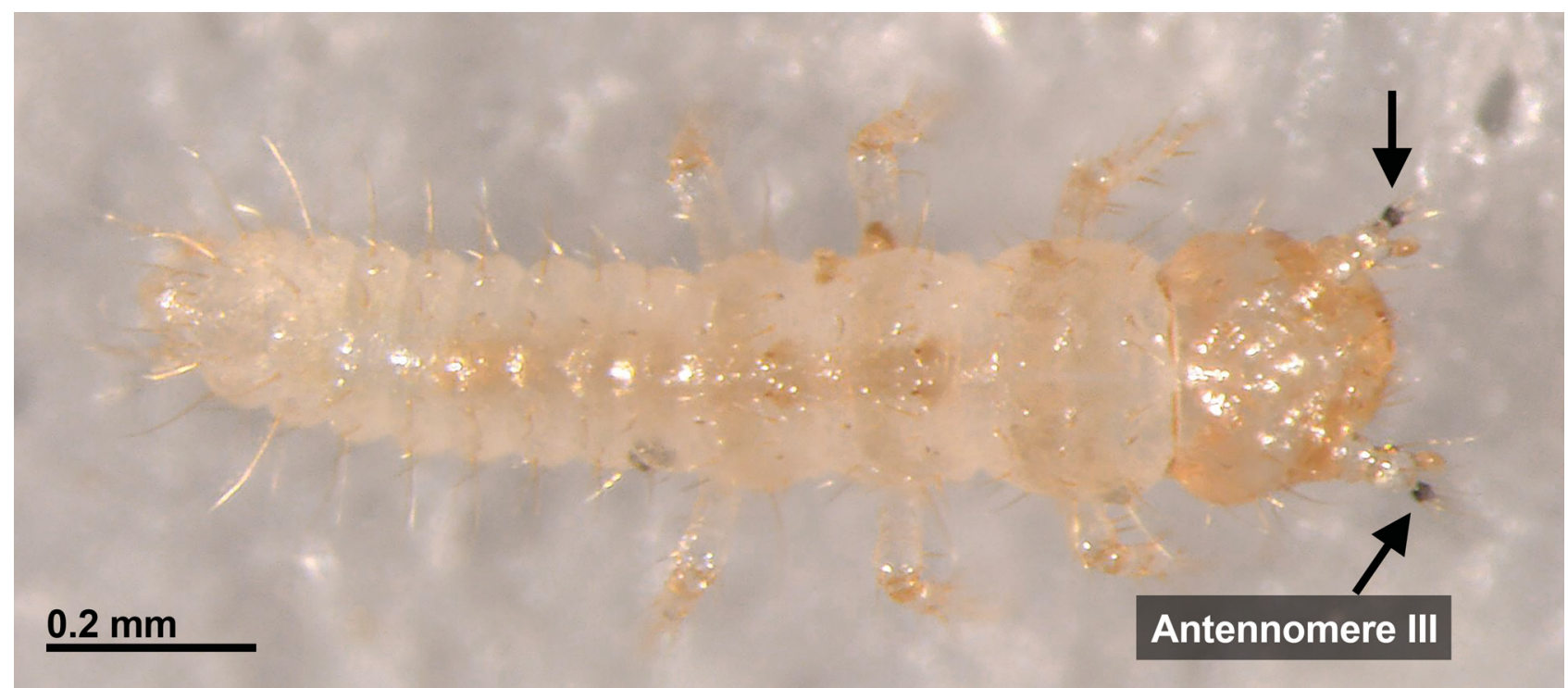

Fig. 4. Living habitus of first instar larva of Japanophilus hojoi Maruyama \& Iwata, 2002. The arrows point to the pigmented antennomeres III.
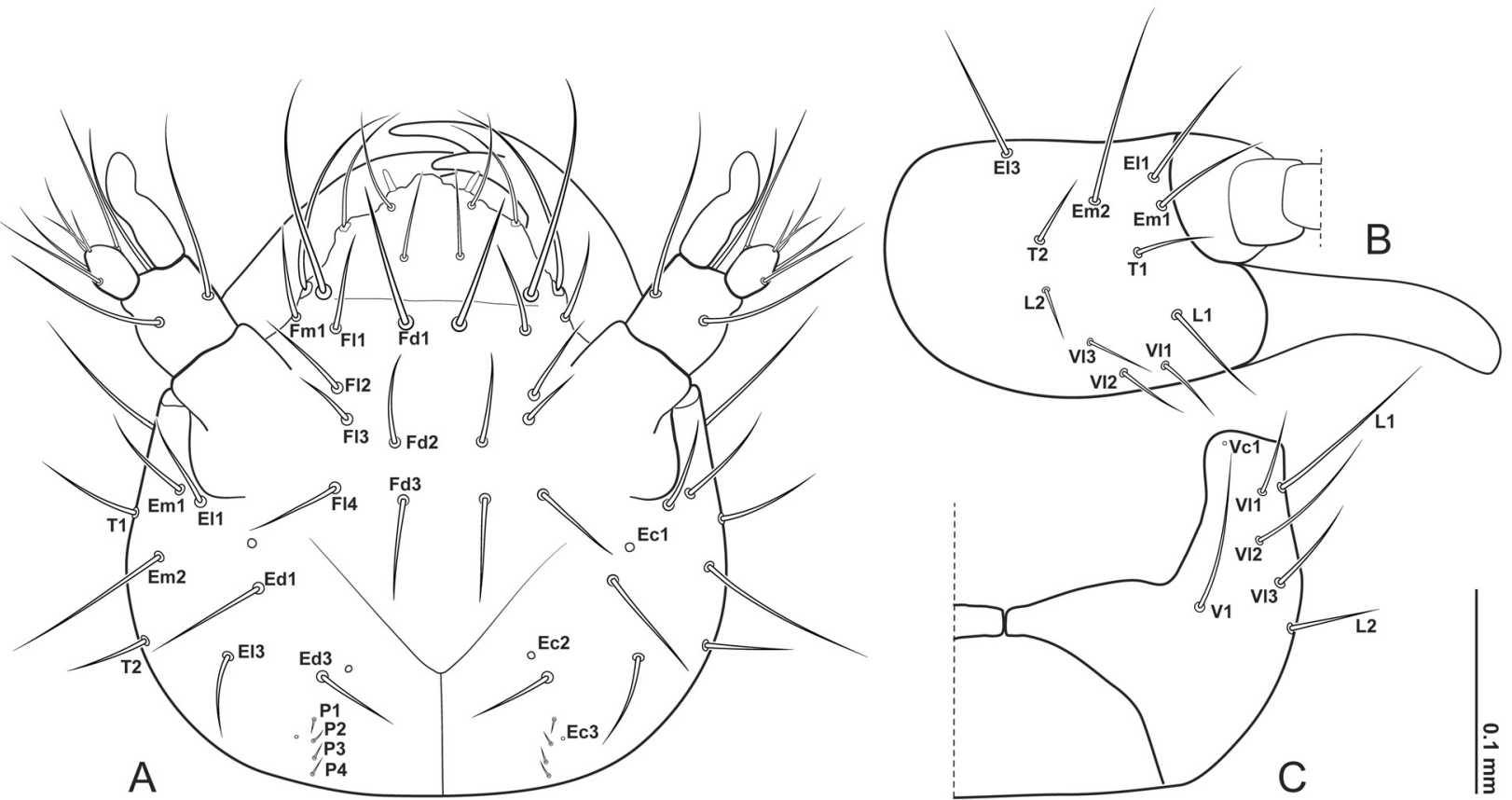

Fig. 5. Japanophilus hojoi Maruyama \& Iwata, 2002, larval instar 1, head. A - dorsal view; B - lateral view; C - ventral view. Abbreviations: Ec - epicranial campaniform sensilla; Ed - epicranial dorsal seta; El - epicranial lateral setae; Em - epicranial marginal setae; Es - epicranial suture; Fd - frontal dorsal setae; Fl - frontal lateral setae; Fm - frontal marginal seta; L - lateral setae; $\mathrm{P}$ - posterior (epicranial) setae; $\mathrm{T}$ - temporal setae; $\mathrm{V}$ - ventral seta; Vc - ventral campaniform sensilla; Vl - ventral lateral setae. 
region. Labrum (Fig. 6B), with 5 pairs of setae (Ld1-2, L11, Lm1-2) on the surface and a pair of campaniform sensilla at anterior margin. Antenna (Figs 6C, D) with 3 articles; article I slightly transverse, length about 0.7 times width, setae absent; article II about 1.5 times as long as I, with 1 short seta, 3 macrosetae (1 dorsal, 1 dorso-medial, and 1 ventro-apical), and a sensory appendage (Figs 6C,
$\mathrm{D}, \mathrm{Sa})$; sensory appendage asymmetrical from dorsal view, approximately 1.2 times as long as article II; article III about 0.5 times as long as II, with 3 large setae and 3 apical solenidia (Figs 6C, D, IIIS1-3). Maxilla (Fig. 6E) with cardo broadly trapezoid, incompletely divided at about middle by sclerotized ridge, with 1 seta on anterolateral margin; stipes broad at base, not distinctly separated from
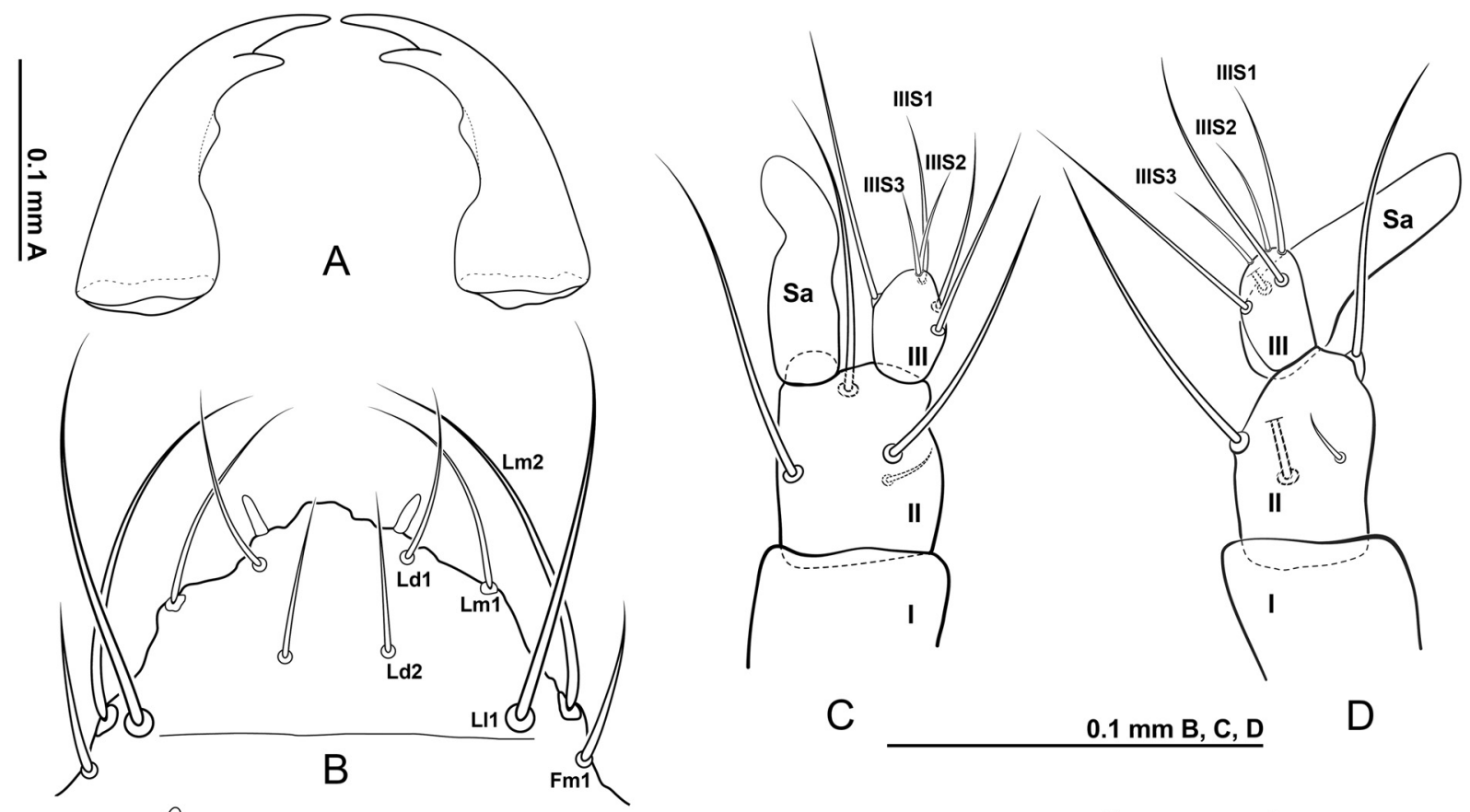

C

$0.1 \mathrm{~mm} \mathrm{~B}, \mathrm{C}, \mathrm{D}$
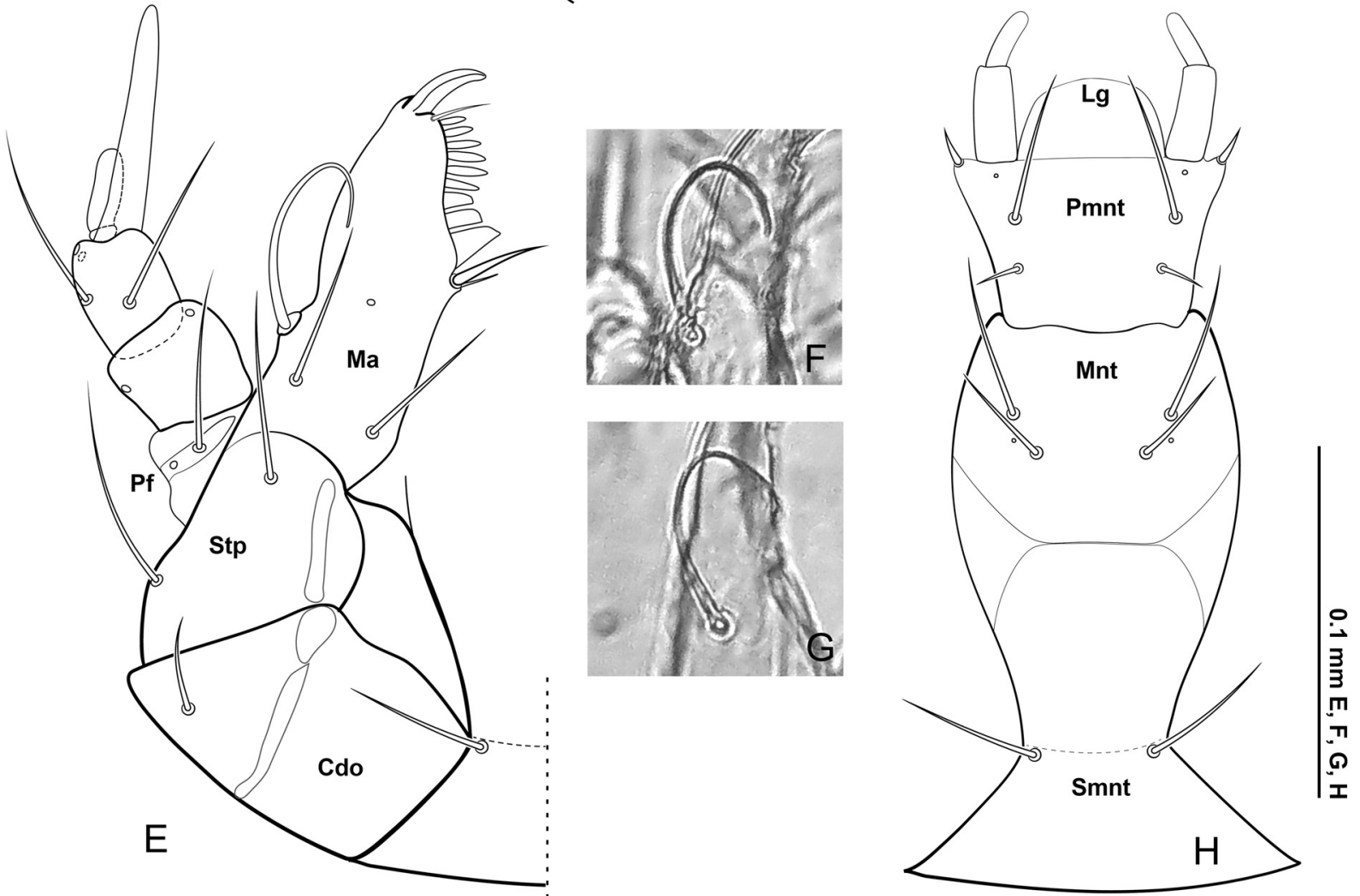

Fig. 6. Japanophilus hojoi Maruyama \& Iwata, 2002, larval instar 1. A - mandibles, dorsal view; B - labrum, dorsal view; C-D - right antenna, dorsal (C) and lateral (D) view; E - right maxilla, ventral view; F-G - curved seta of mala, ventrolateral (F) and lateral (G) view; $H$ - labium, ventral view. Abbreviations: I, II, III - antennal articles; IIIS (1-3) - solenidia of article 3; Cdo - cardo; Fm - frontal marginal seta; Ld - labral dorsal setae; Lg ligula; Ll - labral lateral seta; Lm - labral marginal setae; Ma - mala; Mnt - mentum; Pf - palpifer; Pmnt - prementum; Sa - sensory appendage; Smnt - submentum; Stp - stipes. 
mala, surface with 2 large setae, 1 on disc and 1 at lateral margin. Mala with apex narrowed with an unarticulated apical projection, more basally with an array of comb-like spines distally and 1 long seta at middle on mesal margin; ventral surface of mala with 2 macrosetae at proximal region and 1 curved seta at lateral margin (Figs 6E, F, G).
Palpifer consisting of crescentic sclerite basal to maxillary palpus, ventral surface with 1 seta. Maxillary palpus with 3 articles; article I as long as wide; article II nearly as long as I, width about 0.8 times length; article III slender, about 2 times as long as I, with a digitiform sensory appendage on the base of lateral surface; article I with 2 campaniform

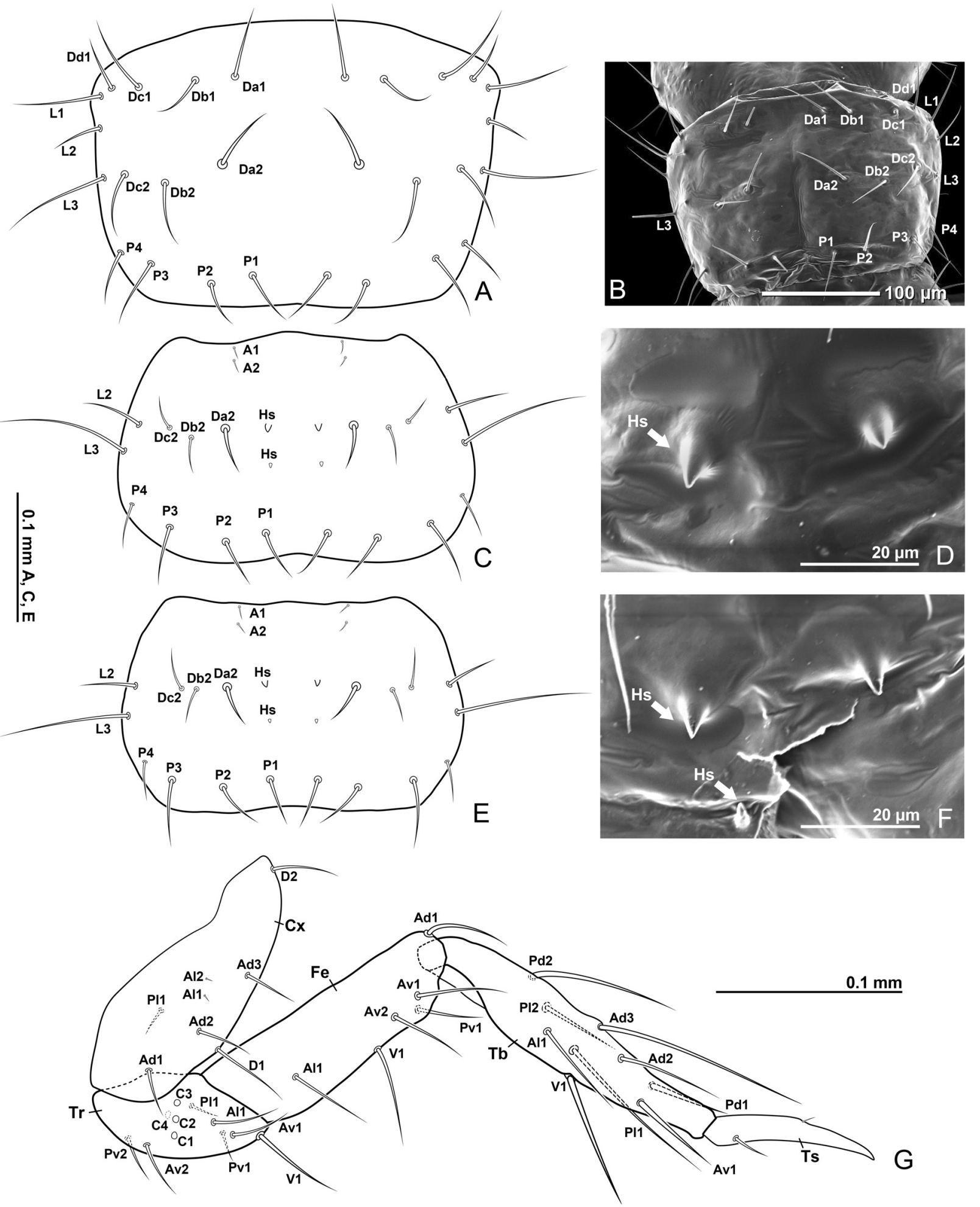

Fig. 7. Japanophilus hojoi Maruyama \& Iwata, 2002, larval instar 1. A-B - pronotum; C - mesonotum; D - hatching spines of mesonotum; E - metanotum; F - hatching spines of metanotum; G - left foreleg, anterior view. Abbreviations: I-X - abdominal segments; A - anterior setae; Ad - anterodorsal setae; Al - anterolateral setae; Av - anteroventral seta; C - campaniform sensilla; Cx - coxa; D - dorsal setae; Da-d - discal setae, rows a-d; Fe - femur; Hs - hatching spines; L - lateral setae; P - posterior setae; Pd - posterodorsal setae; P1 - posterolateral setae; Pv - posteroventral setae; Tb - tibia; Tr - trochanter; Ts - tarsungulus; V - ventral setae. 
sensilla, article II with 2 campaniform sensilla and 2 setae. Labium (Fig. 6H) with ligula semicircular in ventral view, approximately 1.2 times as long as wide; palps with 2 articles, article I nearly 1.5 times as long as II; submentum with 1 pair of setae; mentum with 2 pairs of setae and 1 pair of campaniform sensilla; prementum with 1 pair of apicolateral setae, 2 pairs of discal setae, and 1 pair of campaniform sensille.

Thorax (Figs 4, 7A-F), weakly sclerotized. Pronotum (Figs 7A, B) transverse, with 14 pairs of setae (Da1-2, Db1-2, Dc1-2, Dd1, L1-3, P1-4); mesonotum and metanotum each with 11 setae (A1-2, Da2, Db2, Dc2, L2-3, P1-4); 1 prominent anterior pair and 1 minute posterior pair of hatching spines present beside the center of both mesonotum and metanotum (Figs 7C-F). Ventral side of prothorax with 2 pairs of setae, 1 pair on sternum and 1 on laterally located parts of prehypopleuron. Foreleg as in Fig. $7 \mathrm{G}$; coxa with 4 pairs of setae (Ad1-3, A11-2, D1-2, P11); trochanter with 7 setae (Al1, Av1-2, P11, Pv1-2, V1) and 4 campaniform sensilla ( $\mathrm{C} 1-3$ at anterior field and $\mathrm{C} 4$ at posterior field); femur with 6 setae (Ad1, Al1, Av1-2, Pv1,
V1); tibia with 9 setae (Ad2-3, Al1, Av1, Pd1-2, P11-2, V1); tarsungulus (Ts) with 2 setae (Fig. 7G); length ratio of tarsungulus : tibia : femur $1.0: 2.0: 1.7$.

Abdomen (Figs 4, 8) nearly unsclerotized. Tergites I-VII transverse, similar in shape; tergite VIII oval; chaetotaxy of tergites (Fig. 8A): tergite I with 9 pairs of setae (A2, Da2, Db2, L1, L4, P1, 2, 4, 5); tergites II-VII with 16 setae, chaetotaxy same to tergite I but A1 absent; tergite VIII with 16 setae, chaetotaxy similar to tergite VII but Da2 located at posterior row. Sternites I-VIII transverse, similar in shape (Fig. 8B); sternite I with 8 setae (D1, P1, 3, 5); sternites II-VIII with 12 setae (D1, P1-5) (Fig. 8B). Tergites I-VIII each with a pair of spiracles laterally (Fig. $8 \mathrm{C}, \mathrm{Sp}$ ). Tergal glandular reservoir sac (Tgrs) large, membranous, circular in dorsal view, flattened dorsoventrally (Figs 8A, D, Tgrs). Tergal gland opening (Tgo) markedly developed externally at apex of tergite VIII (Figs 8A, D, Tgo). Segment IX (Figs 8A, C, D, E) with tergite and sternite fused into uniform ring with 20 setae (4 setae dorsally, 12 setae ventrally, and 4 setae laterally). Urogomphi (Figs 8A, C, D, E) 1-segmented, bases fused with segment IX,

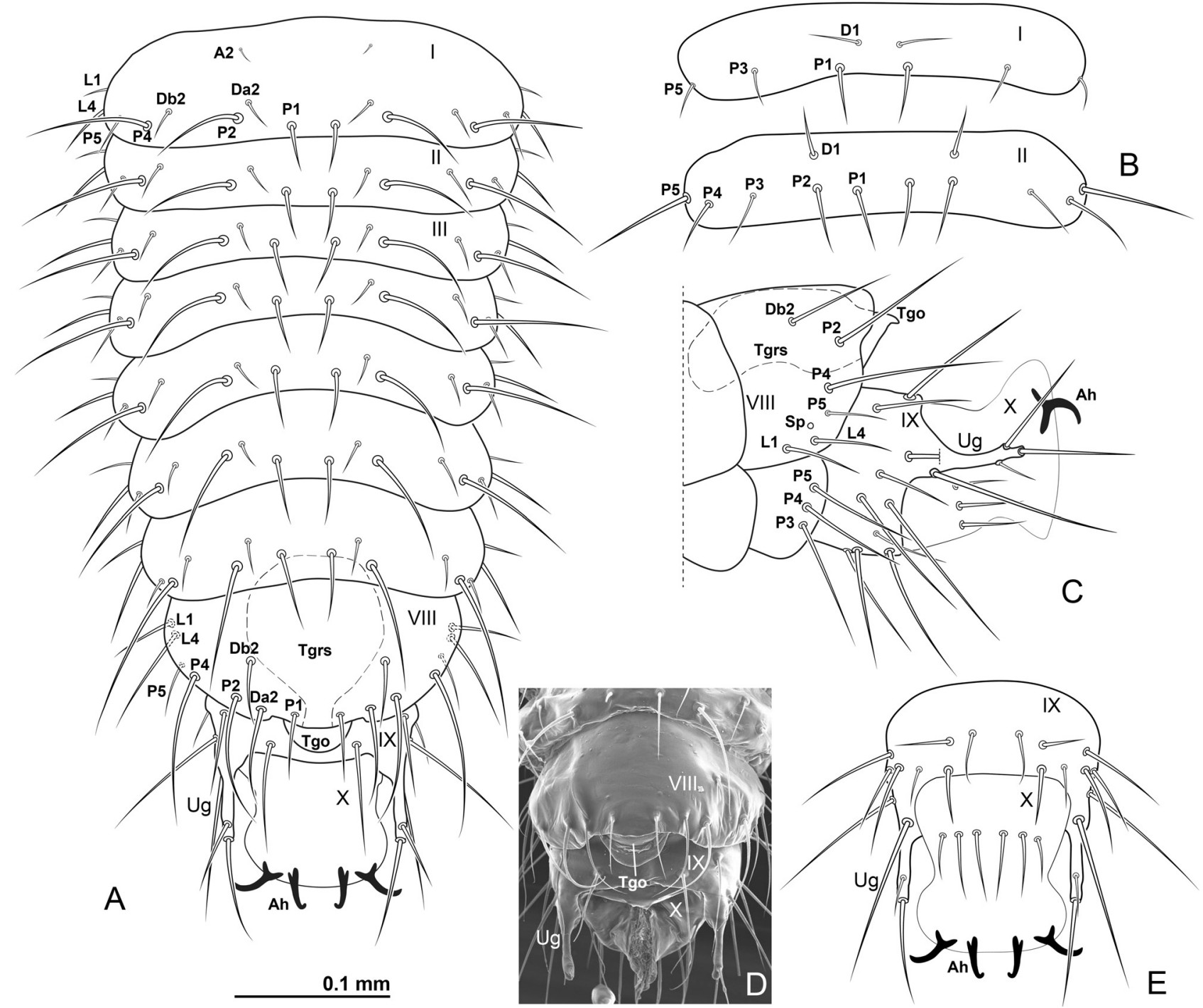

Fig. 8. Japanophilus hojoi Maruyama \& Iwata, 2002, larval instar 1. A - abdominal tergites; B - abdominal sternites I and II; C - abdominal segments VIII, IX, and X, lateral view; D - abdominal tergites VIII, IX, and X; E - abdominal sternites IX and X. Abbreviations: A - anterior setae; Ah - anal hooks; D - discal setae, rows a-d; L - lateral setae; P - posterior setae; Sp - spiracle; Tgrs - tergal glandular reservoir sac; Tgo - tergal gland opening; $\mathrm{Ug}$ - urogomphus. 
each with 1 macroseta at ventral base, 1 seta ventrally at terminal $1 / 4$ of length, 1 macroseta dorsally at terminal 1/5 of length, 1 macroseta apically (Fig. 8C). Abdominal segment X membranous, with 6 setae ventrally, apex with 4 anal hooks (Figs 8A, C, E; Ah).

Remarks. All the larvae examined have black antennomeres III (Fig. 4). This is a typical characteristic for the first larval instar of Aleocharinae (THAYER et al. 2004). Since no larval descriptions have been provided for any Termitohospitini species, the description above provides a foundation for larval knowledge of the genus and tribe.

\section{Discussion}

\section{The natural distributions of the termitohospitine species associated with Coptotermes formosanus}

The Coptotermes formosanus-associated termitohospitine staphylinid beetles had been recorded from China (Zhejiang and Guangdong Provinces) and Japan (Southwest Archipelago, Kyushu Is. and west part of Honshu Is.), and used in interpreting the native range of C. formosanus in those areas (Kistner 1985, MARUYAMA et al. 2012, KANAO et al. 2019). Taiwan, the type locality of $C$. formosanus, was considered unlikely to be part of its native range due to the absence of termitophilous beetles (KISTNER 1985). The present study renews the relevance of Taiwan by finding two species of Termitohospitini, Sinophilus yukoae and Japanophilus hojoi, both formerly only known from Japan. MARUYAMA et al. (2012), inspired by EMERSOn (1955) and Kistner (1969)'s ideas, proposed a so-called "Emerson-Kistner Principle" (EKP) that uses the distribution of host-specific inquilines for delineating the native range of host termites. Both Japanophilus and Sinophilus are thought to be highly host-specific because they are mostly found in C.formosanus nests and collected by flight interception traps in few cases (KANAO et al. 2019, PACE 1998). Thus, their distributions are suspected to be highly constrained with host termite. On the other hand, the non host-specific termitophiles are inadequate to employ in EKP as they are able to transit between different hosts. Therefore, their distributions are not strongly constrained with certain host termite species. However, though not found in termitophiles yet, there were cases that the host-specific myrmecophiles be found other than their native range. For example, the myrmecophilous staphylinid, Myrmecosaurus ferrugenius Bruch, 1932, originated from South America had been introduced into the United States alongside its invasive host ant Solenopsis invicta Buren, 1972 (FrANK 1977). Another similar case was reported from a myrmecophilous scarab, Martineziana dutertrei (Chalumeau, 1983), associated with S. invicta and Solenopsis richteri Forel, 1909 (Collins \& Markin 1971, Wojcik et al. 1977). Such cases show high host specificity is not the only presumption for applying inquilines as indicators of the host's natural distribution range. The factors other than host specificity should be considered, for instance, the degree of host dependence. Martineziana dutertrei is able to feed on dead insects other than the host ants (WOJCIK et al. 1991) and therefore presumed to increase its dispersal ability and also survivorships when transported by human activity. Some of other factors like the life-history (i.e., biology of immature stages, dispersal strategies) and phenology of termitophiles are also crucial and therefore the detailed investigation of termitophiles' life-history should be made to realize their significance in biogeography of host termite.

\section{Systematics and immature stage of Termitohospitini}

The members of the tribe Termitohospitini are known to be termitophilous, mostly associated with Coptotermes Wasmann, 1896 or Nasutitermes Dudley, 1890 (SEEVERS 1941, 1957; KANAO et al. 2012). Adults are mostly found in termite nests, but no immature stages have been reported prior to the present study. Termitohospitini is hypothesized to be closely related to the tribes Myllaenini and Masuriini based on the morphology of the adult mouthparts (KANAO et al. 2012). At present, immature stages are only known for three genera among Myllaenini (THAYER et al. 2004). Based on available information, the larva of Japanophilus hojoi most resembles the larvae of Bryothinusa Casey, 1904 (Aleocharinae: Myllaenini). Of the 30 Bryothinusa species presently described (FRANK \& AHN 2011), larvae of only two species are known: B. catalinae Casey, 1904 and B. koreana Ahn \& Jeon, 2004 (MoOre \& ORTH 1978, JeOn \& AhN 2009). Unfortunately, only descriptions of late instar larvae are available for those two species. As we found only first instar larvae of J. hojoi in the present study, a comprehensive comparison of immature stages between these two genera cannot be made at the present time. However, we noticed high similarity between the larvae of Bryothinusa and Japanophilus by the general shape of the body, head capsule, antenna, mandible, maxilla, and tergal gland opening (see figures in Moore \& OrTh (1978) and JEON \& Ahn (2009) for detail). The similarity of mouthparts, i.e., the form of mala and mandible, reveals the potential similarity of the food resources these larvae consume. Therefore, investigating the feeding behavior of larval Bryothinusa spp. might shed insight into the feeding habits of its termitophilous relatives. On the other hand, the absence of stemmata and the weakly sclerotized body of $J$. hojoi larvae are presumed to be adaptations for life inside and around the termite nest habitat, a moist subterranean environment.

\section{Acknowledgments}

We sincerely thank Dr. Margaret K. Thayer (Field Museum of Natural History, Chicago), Dr. Martin Fikáček (National Museum, Czech Republic), and one anonymous reviewer for improving our manuscript. We also thank Cheng-Lung Tsai (Department of Entomology, NCHU) for technical support on gene sequencing. We thank Fang-Shuo $\mathrm{Hu}$ (Department of Entomology, NCHU) for providing specimens from Taipei and Yilan. We thank Kuan-Chih Kuan (Department of Entomology, NCHU) for sharing important comments. This study was supported by funding from Japan-Taiwan Exchange Association for WRL and the grants (MOST 104-2311-B-005-002 and MOST 105-2628-B-005-003-MY3) provided by the Ministry of Science and Technology, Taiwan. 


\section{References}

ASHE J. S. \& WATROUS L. E. 1984: Larval chaetotaxy of Aleocharinae (Staphylinidae) based on a description of Atheta coriaria Kraatz. Coleopterists'Bulletin 38: 165-179.

AUSTIN J. W., SZALANSKI A. L., SCHEFFRAHN R. H., MESSENGER M. T., McKERN J.A. \& GOLD R. E. 2006: Genetic evidence for two introductions of the Formosan subterranean termite, Coptotermes formosanus (Isoptera: Rhinotermitidae), to the United States. Florida Entomologist 89: 183-193.

CHIU C.-I., YEH H.-T., TSAI M.-J. \& LI H.-F. 2016: Naturalization and control of Coptotermes gestroi (Blattodea: Rhinotermitidae) in a Taiwanese Forest. Journal of Economic Entomology 109: 1317-1325.

COLLINS H. L. \& MARKIN G. P. 1971: Inquilines and other arthropods collected from nests of the imported fire ant, Solenopsis saevissima richteri. Annals of the Entomological Society of America 64: 1376-1380.

ELVEN H., BACHMANN L. \& GUSAROV V. I. 2012: Molecular phylogeny of the Athetini-Lomechusini-Ecitocharini clade of aleocharine rove beetles (Insecta). Zoologica Scripta 41: 617-636.

EMERSON A. E. 1955: Geographical origins and dispersions of termite genera. Fieldiana, Zoology 37: 465-521.

EVANS T. A., FORSCHLER B. T. \& GRACE J. K. 2013: Biology of invasive termites: a worldwide review. Annual Review of Entomology 58: $455-474$.

FRANK J. H. 1977: Myrmecosaurus ferrugineus, an Argentinian beetle from fire ant nests in the United States. Florida Entomologist 60: 31-36.

FRANK J. H. \& AHN K.-J. 2011: Coastal Staphylinidae (Coleoptera): A worldwide checklist, biogeography and natural history. ZooKeys 107: 1-98.

HADLEY A. 2010: CombineZP. (Official website no longer available).

HALL T. A. 1999: BioEdit: a user-friendly biological sequence alignment editor and analysis program for Windows 95/98/NT. Nucleic Acids Symposium Series 41: 95-98.

HUSSENEDER C., SIMMS D. M., DELATTE J. R., WANG C., GRACE J. K. \& VARGO E. L. 2012: Genetic diversity and colony breeding structure in native and introduced ranges of the Formosan subterranean termite, Coptotermes formosanus. Biological Invasions 14: 419-437.

JEON M.-J. \& AHN K.-J. 2009: Description of late-instars of Bryothinusa koreana Ahn and Jeon (Coleoptera: Staphylinidae: Aleocharinae) by association of life stage based on DNA sequence data. Florida Entomologist 92: 367-373.

KANAO T., ELDREDGE K. T. \& MARUYAMA M. 2012: Two new genera and species of the termite symbiont lineage Termitohospitini (Coleoptera, Staphylinidae, Aleocharinae) from Bolivia and peninsular Malaysia. ZooKeys 254: 67-87.

KANAO T., IWATA R., SASAKI T., HIROSE H. \& YOSHIMURA M. 2019: New distributional records of two termitophilous rove beetles (Coleoptera, Staphylinidae) in Japan. Elytra, New Series 9: 39-40.

KISTNER D. H. 1969: The biology of termitophiles. Pp. 525-557. In: KRISHNA K. \& WEESNER F. M. (ed.): Biology of termites. Vol. 1. Academic Press, New York, 612 pp.

KISTNER D. H. 1979: Social and evolutionary significance of social insect symbionts. Pp. 339-413. In: HERMANN H. R. (ed.): Social insects. Vol. 1. Academic Press, New York, 454 pp.

KISTNER D. H. 1985: A new genus and species of termitophilous Aleocharinae from mainland China associated with Coptotermes formosanus and its zoogeographic significance (Coleoptera: Staphylinidae). Sociobiology 10: 93-104.
KUMAR S., STECHER G., LI M., KNYAZ C. \& TAMURA K. 2018: MEGAX: molecular evolutionary genetics analysis across computing platforms. Molecular Biology and Evolution 35: 1547-1549.

LI H.-F., YE W., SU N.-Y. \& KANZAKI N. 2009: Phylogeography of Coptotermes gestroi and Coptotermes formosanus (Isoptera: Rhinotermitidae) in Taiwan. Annals of the Entomological Society of America 102: 684-693.

MARUYAMA M. \& IWATA R. 2002: Two new termitophiles of the tribe Termitohospitini (Coleoptera: Staphylinidae: Aleocharinae) associated with Coptotermes formosanus (Isoptera: Rhinotermitidae). Canadian Entomologist 134: 419-432.

MARUYAMA M., KANAO T. \& IWATA R. 2012: Discovery of two aleocharine staphylinid species (Coleoptera) associated with Coptotermes formosanus (Isoptera: Rhinotermitidae) from central Japan, with a review of the possible natural distribution of $\mathrm{C}$. formosanus in Japan and surrounding countries. Sociobiology 59: 605-616.

MOORE I. \& ORTH R. 1979: Notes on Bryothinusa with description of the larva of B. catalinae Casey (Coleoptera: Staphylinidae). Psyche 85 [1978]: 183-189.

PACE R. 1998: Aleocharinae della Cina: Parte I (Coleoptera, Staphylinidae). Revue Suisse de Zoologie 105: 139-220.

PIMENTEL D., ZUNIGA R. \& MORRISON D. 2005: Update on the environmental and economic costs associated with alien-invasive species in the United States. Ecological Economics 52: 273-288.

POSADA D. 2008: jModelTest: phylogenetic model averaging. Molecular Biology and Evolution 25: 1253-1256.

SCHÜLKE M. \& SMETANAA. 2015: Staphylinidae. Pp. 901-1134. In: LÖBL I. \& LÖBL D. (eds): Catalogue of Palaearctic Coleoptera. Volume 2. Brill, Leiden, 1702 pp.

SEEVERS C. H. 1941: Taxonomic investigations of some termitophilous Staphylinidae of the subfamilies Aleocharinae and Trichopseniinae (new subfamily). Annals of the Entomological Society of America 34: $318-349$

SEEVERS C. H. 1957: A monograph on the termitophilous Staphylinidae: Coleoptera. Fieldiana, Zoology 40: 1-334.

SHIRAKI T. 1909: (On some termite species of Japan). Transactions of the Entomological Society of Japan 2: 229-242 (in Japanese).

STANIEC B., PIETRYKOWSKA-TUDRUJ E. \& PILIPCZUK J. 2009: Morphology of the developmental stages of Pella (Zyras) laticollis (Märkell, 1844) with remarks on its biology (Coleoptera: Staphylinidae). Genus 20: 225-242.

SU N.-Y., BAN P. M. \& SCHEFFRAHN R. H. 1993: A shallow subsurface monitoring station for subterranean termites (Isoptera). Sociobiology 23: 175-182.

THAYER M. K., ASHE J. S. \& HANLEY R. S. 2004: Discovery of the remarkable larvae of Hoplandriini (Coleoptera: Staphylinidae: Aleocharinae). Annals of the Entomological Society of America 97: 624-634.

WANG J. \& GRACE J. K. 2000: Genetic relationship of Coptotermes formosanus (Isoptera: Rhinotermitidae) populations from the United States and China. Sociobiology 36: 7-19.

WOJCIK D. P., BANKS W. A., HICKS D. M. \& SUMMERLIN J. W. 1977: Fire ant myrmecophiles: new hosts and distribution of Myrmecaphodius excavaticollis (Blanchard) and Euparia castanea Serville (Coleoptera: Scarabaeidae). Coleopterists'Bulletin 31: 329-334.

WOJCIK D. P., SMITTLE B. J. \& CROMROY H. L. 1991: Fire ant myrmecophiles: feeding relationships of Martinezia dutertrei and Euparia castanea (Coleoptera: Scarabaeidae) with their host ants, Solenopsis spp. (Hymenoptera: Formicidae). Insectes Sociaux 38: 273-281. 
